\title{
Research on the Interactive Development of Dong Village Cultural Heritage Protection and Night Tourism: a Case Study of Huangdu Dong Village in Hunan
}

\author{
Mengyao Tian ${ }^{1}$, Wenjun Zheng ${ }^{1, *}$, and Na Wang ${ }^{1}$ \\ ${ }^{1}$ College of Tourism \& Landscape Architecture, Guilin University of Technology, Guilin 541004, China
}

\begin{abstract}
Under the policy of cultural tourism integration, the huge economic and social benefits brought by night tourism are gradually recognized. Based on the compatibility, in response to the needs of cultural heritage protection and night tourism development in the Southwest Dong area, a driving mechanism for night tourism and cultural heritage live protection with the spirit of place as the core is proposed. Taking the Huangdu Dong Village in Hunan as an example, the research explored the traditional night culture of Dong Village, analysed the development status of night tourism, and proposed interactive development strategies for Dong Village night tourism and cultural heritage protection, which will help the destination resource allocation shift from space expansion to time expansion and accelerate its innovative development on the basis of the protection of the authenticity of cultural heritage. The research has certain reference significance for the survival of traditional culture and the innovative development of tourism in ethnic minority villages.
\end{abstract}

\section{Introduction}

With the development of society, the cultural spirit contained in the cultural heritage is constantly experiencing the impact of external culture and the test of the times, and the existence of national cultural heritage has important value for the overall protection of villages. Dong nationality is one of the most important ethnic groups in Southwest China. As the core of Dong ethnic cultural identity, cultural heritage has a long history in its formation and development. At present, the research on the cultural heritage of the Dong nationality area mainly includes the following perspectives: selecting specific types for special research ${ }^{[1-2]}$; analysing the protection and utilization from the perspective of tourism industry development ${ }^{[3-5]}$; exploring the protection ways from the perspective of digital and other emerging technologies ${ }^{[6]}$. Dong family coexists in the interaction with cultural heritage, and gradually forms a unique Dong cultural space system. The study of Dong cultural heritage is conducive to the continuation of the cultural space.

In the tourism application of Dong cultural heritage, night tourism is a new way under the background of cultural and tourism integration. It has the characteristics of diversified scenes, high product quality requirements and easy homogeneity. Due to the cultural particularity of the Dong area, the development of night tourism should be based on the protection of cultural heritage, and the "Dong mode" can make the cultural heritage value rejuvenate. Taking Huangdu Dong Village in Hunan as an example, the study puts forward a strategy of interactive development of cultural heritage protection and night tourism, which helps to think on how to protect the cultural heritage of the Dong nationality from a new perspective in the constantly updated environment.

\section{Cultural heritage protection and night tourism}

\subsection{Compatibility analysis of cultural heritage protection and night tourism development}

The cultural heritage of a specific region is formed by the combination of regional material culture and intangible culture. The point of interaction between cultural heritage protection and night tourism is the overall protection of the spirit of heritage sites. The place spirit of heritage sites mainly includes original community, material elements and intangible elements. The material and intangible elements constitute the core of the cultural heritage. With the external groups of the night tourism, the connotation system of night tourism and cultural heritage protection is formed (Fig. 1).

The place spirit of the Dong nationality mainly includes the relationship between people and the external architectural space and internal culture. The exterior is surrounded by mountains and rivers, and the interior is distributed in clusters with drum towers as the center and family surnames. Site selection wisdom represented by Fengshui culture, the agricultural spirit represented by rice culture, the governance model represented by the Kuan culture, and the belief system represented by the primitive nature worship constitute the core of the spirit of the place, which is an important carrier of night tourism. Night

\footnotetext{
Corresponding author: 511897198@qq.com
} 
tourism is the tangible and intangible creative interaction of the place spirit, which forms one of the means of "cultural protection" of cultural heritage. Therefore, the protection of the place spirit is a good meeting point for the interactive development of cultural heritage and night tourism.

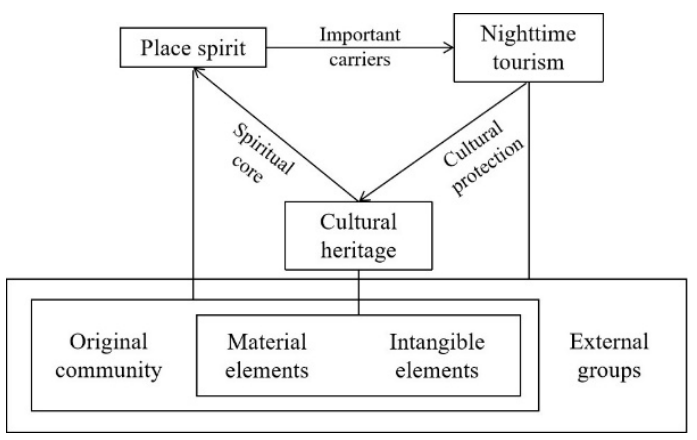

Fig. 1. Connotation Analysis of Cultural Heritage and Night Tourism.

\subsection{Driving Mechanism of Cultural Heritage Protection under Night Tourism}

Night tourism is mainly motivated by the activation of cultural heritage. The active protection mechanism system of Dong village cultural heritage under night tourism constructed in this paper (Fig. 2) mainly includes thrust role (market supply), pull role (social demand) and media. The main body of the Dong village place spirit is the primitive community, and it is the core stakeholder of living protection ${ }^{[7]}$; by excavating the night culture of Dong village and using primitive communities as the main influence group, we can enrich the place spirit and maintain the national identity of primitive residents; ethnic minority cultural heritage contains rich heritage value, which is helpful to heritage conservation after scientifically verified by relevant experts; the value of heritage must be used and inherited in protection, and while pursuing social and environmental benefits, it's an effective way to help the poor by tourism to meet economic needs of ethnic minority areas; using the golden 4 hours at night can enrich Dong village's tourism industry and meet the needs of night tourism activities. It is also one of the ways to realize the innovative development of the local tourism industry.

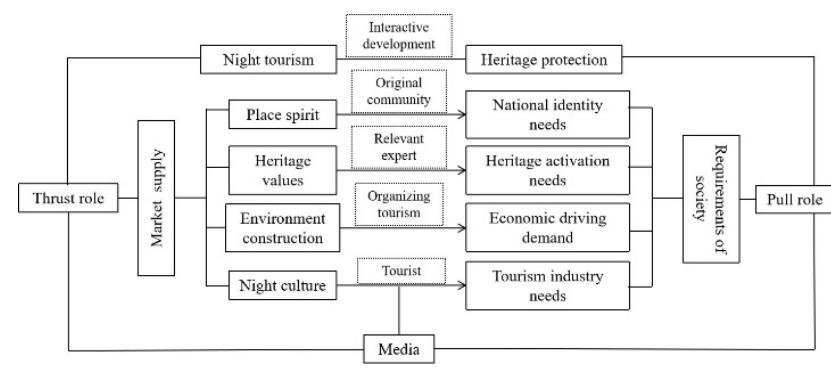

Fig. 2. Driving Mechanism of Cultural Heritage Protection under Night Tourism.

\section{Traditional night activities and cultural value of Huangdu Dong Village in Hunan}

\subsection{General Situation of Huangdu Dong Village in Hunan}

Huangdu Dong Village is located in the central area of "Baili Dong Cultural Corridor" in Tongdao Dong Autonomous County, Hunan Province. It is a national AAAA scenic spot with a long history and a high degree of tourism development. The village is composed of Touzhai, Panzhai, Weizhai and Xinzhai. The traditional Dong architecture is intact, and the buildings such as wind-rain bridge, gazebo, the village gate and drum-tower are the essence of Dong culture. The village has a strong primitive Dong customs and is known as the "original version" of a harmonious society, resulting in a number of intangible cultural heritages (Tab.1).

Table 1. Intangible Cultural Heritage Project of Huangdu Dong Village in Hunan.

\begin{tabular}{|c|c|}
\hline $\begin{array}{c}\text { world immaterial } \\
\text { heritages }\end{array}$ & Dong Songs \\
\hline $\begin{array}{c}\text { National intangible } \\
\text { cultural heritage }\end{array}$ & $\begin{array}{c}\text { Dong Lusheng、Dong brocade } \\
\text { weaving techniques、Dong } \\
\text { drama }\end{array}$ \\
\hline $\begin{array}{c}\text { Provincial intangible } \\
\text { cultural heritage }\end{array}$ & $\begin{array}{c}\text { Dawuliang Song Fair、Dong } \\
\text { kuan、Building Techniques of } \\
\text { Wooden Structure of Dong } \\
\text { Nationality }\end{array}$ \\
\hline $\begin{array}{c}\text { Municipal intangible } \\
\text { cultural heritage }\end{array}$ & $\begin{array}{c}\text { Dong "weiye" Festival Dong } \\
\text { Sa Sui Faith、Dong marriage } \\
\text { customs、Dong clothing }\end{array}$ \\
\hline
\end{tabular}

\subsection{Traditional Night Activities in Huangdu Dong Village in Hunan}

As an important component of ethnic minorities in the southwest region, the Dong nationality has unique natural geographical conditions and unique national cultural heritage treasures. The traditional culture contains various night culture activities, which are important manifestation of the night culture of Huangdu Dong Village. The traditional night activities of the village can be divided into three types: traditional festivals, social activities, and religious sacrifices(Tab.2).

Table 2. Main traditional night activities of Dong Nationality.

\begin{tabular}{|c|c|c|}
\hline Types & $\begin{array}{c}\text { Representative } \\
\text { activities }\end{array}$ & Main content \\
\hline \multirow{4}{*}{$\begin{array}{c}\text { Traditional } \\
\text { festivals }\end{array}$} & Spring festival & $\begin{array}{c}\text { Shousui and Tiansui in } \\
\text { New year's Eve }\end{array}$ \\
\cline { 2 - 3 } & $\begin{array}{c}\text { March 3rd } \\
\text { festival } \\
\text { fingming }\end{array}$ & $\begin{array}{c}\text { Taking the feast which } \\
\text { have a long table and } \\
\text { lots of foods }\end{array}$ \\
\cline { 2 - 3 } & $\begin{array}{c}\text { Guanyangmen } \\
\text { festival }\end{array}$ & $\begin{array}{c}\text { Fellowship and } \\
\text { celebration activities }\end{array}$ \\
\hline
\end{tabular}




\begin{tabular}{|c|c|c|}
\hline & Chage Festival & $\begin{array}{c}\text { Fellowship and } \\
\text { celebration activities }\end{array}$ \\
\hline \multirow{3}{*}{$\begin{array}{c}\text { Social } \\
\text { activities }\end{array}$} & Xinggezuoyue & $\begin{array}{l}\text { Holding fellowship in } \\
\text { the "Yuetang" }\end{array}$ \\
\hline & $\begin{array}{l}\text { Stealing dish } \\
\text { under the moon }\end{array}$ & $\begin{array}{l}\text { The woman "steal" the } \\
\text { leeks and spring onions } \\
\text { from the field of the } \\
\text { man she liked at night }\end{array}$ \\
\hline & Duogaobei & $\begin{array}{l}\text { Throwing firewood } \\
\text { heads across the bank in } \\
\text { the village as a unit for } \\
\text { the competition }\end{array}$ \\
\hline \multirow{3}{*}{$\begin{array}{l}\text { Religious } \\
\text { sacrifices }\end{array}$} & $\begin{array}{c}\text { Daily family } \\
\text { sacrifices }\end{array}$ & $\begin{array}{l}\text { Taking food for } \\
\text { Sacrifice }\end{array}$ \\
\hline & $\begin{array}{l}\text { Sacrifices of } \\
\text { Mid-July }\end{array}$ & $\begin{array}{l}\text { Taking food for } \\
\text { Sacrifice }\end{array}$ \\
\hline & $\begin{array}{l}\text { Ancestor "SA" } \\
\text { worship }\end{array}$ & "Laobing" and "Xisa" \\
\hline
\end{tabular}

\subsubsection{Traditional festivals}

Due to the closure, Dong people have produced many characteristic Dong festival activities with the change of the seasons, such as the Tea Song festival on July 15 or August 15, the "Longxi" at the dinner on March 3 and the "Dousha" at the night of the Qingming Festival .With the development of the times, there have also emerged new festivals of multicultural integration, such as the Spring Festival.

\subsubsection{Social activities}

In addition to the entertainment activities carried out in traditional festivals, there are also some social activities for communicating with friends, such as the traditional love social activities "Xinggezuoyue", happened in "Yuetang", the "Stealing moon vegetables" on the eve of the Mid-Autumn Festival, and "Duogaobei", which used village as a unit to throw firewood heads across the bank for competitions.

\subsubsection{Religious sacrifices}

The earliest worship of the Dong people is the worship of female ancestors, and then it has been derived into corresponding ancestor worship, tribal ancestor worship, ancestor worship, and family ancestor worship ${ }^{[8]}$. So there are corresponding ancestor sacrifices, tribal ancestor worship, ancestor sacrifices, and family ancestor sacrifices. Some of the rituals will carry out all or part of the activities at night, such as the three procedures of "July and a half" family sacrifice, food sacrifice and "Shaobao"; "Laobing" and "Xisa" during the largest ritual event "Jisa". The sacred Dong sacrificial activities add mystery to the Dong night culture.

\subsection{Cultural value and significance}

Traditional night culture of the Dong nationality has the value and significance: the traditional night culture embodies the local spirit from the aspects of space and culture. It not only promotes the benign interaction among the village and other villages, but also is the core cohesive force of the Dong nationality's traditional culture. Secondly, it links the material and intangible elements of the Dong's cultural heritage. The development of night tourism based on the traditional night activities is an effective way to protect and utilize the cultural heritage of the Dong nationality.

\section{Suitability analysis of night tourism development in Huangdu Dong Village in Hunan}

\subsection{Development status of night tourism of Huangdu Dong Village}

According to the field investigation, Huangdu Dong Village has a good foundation for the development of night tourism, but there are some improvements. As for the external environment, Huangdu Dong Village has simply illuminated the main architectural landscape in the village, but it still lacks the "night" atmosphere tourists really pursue. The activity area is small, mainly concentrated in the performance stage next to the Jifeng Drum Tower and the main street. As for night activities, traditional singing and dancing performances and bonfire collective interaction activities are the main ones. These activities make Dong traditional cultural activities, such as "Duoye", and foreign cultures are incorporated. They have a strong degree of participation, but they do not fully show the night culture tradition. In general, Huangdu Dong Village has rich nighttime tourism resources, but the current development is still lacking. Most tourists choose to leave after the end of night activities. How to present the most primitive night culture of Dong nationality to tourists in a short time has great potential.

\subsection{Suitability of night tourism development of Huangdu Dong Village}

From the four aspects of primitive communities, material elements, intangible elements, and external groups included in night tourism, Huangdu Dong Village has a good interactive development suitability for the protection of Dong cultural heritage. First of all, Huangdu Dong Village has professional tourism companies to develop local tourism and the level of tourism development is relatively mature. In addition to the elderly in the village, many young people return to their hometowns to develop tourism-related industries. Compared with other Dong villages whose original features are better preserved but are seriously aging, the original community of Huangdu Dong Village is relatively complete; for the material and intangible elements contained in the cultural heritage, in addition to the landscape renovation for tourism 
development in the central area, the original style and customs still retain the original Dong characteristics, and there are many traditional night activities that can be extended to night tourism.; the tourism industry is managed by a tourism company, and the folk art troupe, the Lusheng team, and the Dong opera troupe, have been established to create the performance "Dong Hearing, Sound of Nature", which shows that the tourism industry has a relatively good foundation and a relatively stable source of tourists. On this basis, continuing to develop night tourism will produce better results.

\section{Cultural heritage protection and night tourism interactive development strategy of Huangdu Dong Village in Hunan}

Taking the protection of the cultural heritage of the Dong nationality as the original intention, based on the live protection mechanism of cultural heritage under night tourism, the protection of cultural heritage and night tourism in the Dong village should be interactively developed from the following perspectives:

\subsection{Activating Dong cultural symbols and creating Dong night tour IP}

With modern means, we should extract the Dong elements in the cultural landscape such as buildings and scenes, find the connection point between Dong and modern society, precisely position the market demand, and design cultural and creative products. In addition, make full use of nature and Dong culture to create characteristic night landscape nodes to highlight the Dong night country interest. Besides, combined with the cultural, heterogeneous and pluralistic characteristics, we can highlight the characteristics of Dong's night culture, and create a night tourism cultural brand. By arousing the spiritual resonance of tourists, the social communication of cultural IP will be realized.

\subsection{Using technology to integrate night culture and tourism, creating a new context of night culture}

Under the background of integration of culture and tourism, scientific and technological innovation is an important engine to realize the high-quality development of tourism. Many scenic spots rely on the implantation of science and technology to rejuvenate the original tourism resources. For example, the Palace Museum integrates 8K ultra high definition digital interactive technology and 4D dynamic images to rejuvenate the traditional cultural heritage. For the Dong village of "Living State Museum", it is possible to connect the internal nodes by immersive theatre and other scientific and technological ways to form a night tourism loop, so that tourists can integrate into the local environment to the greatest extent and experience the traditional Dong family's night activities.

\subsection{Encouraging community participation mechanism to realize the real benefit of villagers}

Among the many subjects in the development of night tourism in Dong villages, the villagers are the most affected. For villagers, tourism rights should be confirmed When tourism developers enter villages, the role of "front desk" of residents should be defined to provide opportunities for local villagers to directly or indirectly participate in tourism decision-making. What's more, taking advantage of the residents' understanding of the traditional night culture, the villagers should be provided with opportunities to participate directly in tourism operations, such as scenic interpretation, catering services, stage performances. Besides, encourage them to maintain the most traditional living customs, display the most distinctive Dong culture to tourists, and use the golden 4hour leisure time at night to bring more economic benefits.

\section{Conclusion}

There are abundant night cultural activities in Huangdu Dong village. The optimized interactive development of night tourism will have a good impact in many aspects: for the local landscape, the night environment set off by the coordinated mapping of light will integrate the unique cultural connotation and visual aesthetics of Dong villages, and highlight the ancient rural taste of Dong villages; for the aborigines, the benign development of night tourism will make them realize the new value of Dong cultural heritage, and arouse the awareness of protecting them, which is the consolidation of the local cultural spirit; for the local tourism market, it is the innovation of tourism format and the further development of the market. The interactive development of Dong village cultural heritage protection and night tourism will be of enlightening significance to other ethnic minority areas in China, which can not only promote the innovative development of local tourism, but also help the cultural cohesion and spiritual inheritance of the nation.

\section{Acknowledgment}

Supported by: Humanity and Social Science Youth Foundation of Ministry of Education of China (19YJC850027) ;

Innovation Project of Guangxi Graduate Education (YCSW2020178)

\section{References}

1. B.W.Yang, CLA, 34, 102-106(2018)

2. Z.B.Liu, JOOENC, 9, 125-127(2017)

3. N.Gong, GES, 39, 61-66(2018)

4. J.Zhang, Z.J.Wu, HG, 26, 83-88(2011)

5. J.H.Yang, JOSMU, 33, 131-136(2012)

6. L.Yao, JOGEU, 35, 12-18(2019)

7. X.M.Zhao, Spatial Cultural Expression of Living Rural Settlements in China -- A Case Study of Dong 
Village in Southeast Guizhou Province, (Nanjing :Southeast University Press, 2014)

8. M.Zhang, GES, 46-51(1995) 